\title{
Moja Polska? - dyskursy tożsamościowe w edukacji polonistycznej
}

\author{
My Poland? - identity discourses in Polish language \\ education
}

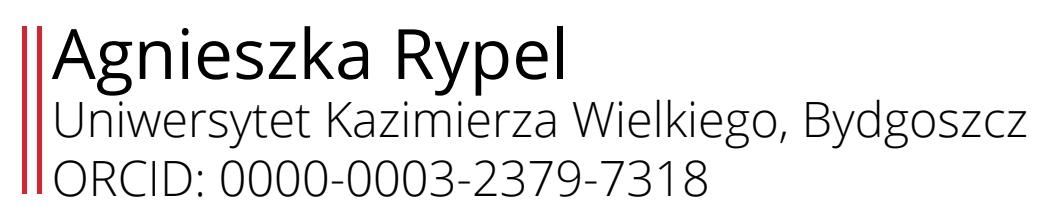

\begin{abstract}
The aim of the article is to define the essence of national identity of education discourse. Institutional education plays the crucial role to pass on this identity. These institutions are in power to influence young generations attending primary and compulsory schools. This way every student is given the same meaning of different social phenomenon, common cultural patterns and even patterns of interpreting the place of individual in the group - most of all in the nation.

This article is devoted to the analysis of the patterns of national identity of different kinds of texts placed in the textbooks and shows topos, myths and symbols shaping this identity. The textbooks analysis proceeds on synchronous and diachronic ground. This analysis shows that currently school education does not have a great impact on the national identity of the young generation and each student shapes his/her national identity through his/her own affiliation of different patterns.
\end{abstract}

Key words: national identity, national and cultural affiliation, topos, myths and national symbols, Polish language textbooks

Streszczenie: Celem artykułu jest zdefiniowanie istoty narodowej tożsamości w dyskursie edukacyjnym. Edukacja instytucjonalna odgrywa kluczową rolę w przekazywaniu tej tożsamości. Szkoły jako instytucje państwowe mają wpływ na całe młode pokolenia obowiązkowo uczęszczające do szkół podstawowych. W ten sposób każdemu uczniowi przekazuje się ten sam sposób rozumienia różnych zjawisk społecznych, wspólne wzorce kulturowe, a nawet wzory interpretacji miejsca jednostki w grupie - przede wszystkim we wspólnocie narodowej.

Artykuł poświęcony jest analizie wzorów tożsamości narodowej w różnego rodzaju tekstach zamieszczanych w podręcznikach, wskazuje toposy, mity i symbole kształtujące tę tożsamość. Analiza podręczników przebiega na poziomie synchronicznym i diachronicznym i pokazuje, że obecnie edukacja szkolna nie ma wielkiego wpływu na tożsamość narodową młodego pokolenia, i że każdy uczeń kształtuje swoją tożsamość narodową poprzez własną afiliację różnych wzorców tej tożsamości.

Słowa kluczowe: tożsamość narodowa, afiliacja narodowa i kulturowa, toposy, mity i symbole narodowe, podręczniki do języka polskiego 
Najogólniej rzecz ujmując, tożsamość to świadomość siebie, zdolność określenia, kim się jest, do jakiej grupy się należy, z jaką grupą się identyfikuje i do jakiej się przyznaje. Jest to rodzaj samowiedzy dotyczącej tego, co dla jednostki najważniejsze, najbardziej charakterystyczne, co ją tworzy, jest jej istotą i co określa refleksyjny stosunek podmiotu do samego siebie (Budyta-Budzyńska 2010, 91).

Nie można precyzyjnie określić ani w wymiarze psychologicznym, ani społecznym czy narodowym cech tożsamości jednostkowej młodych ludzi będących uczniami współczesnej szkoły i to nie tylko na skutek trudności metodologicznych i logistycznych szeroko zakrojonych badań, ale także dlatego, że niełatwo przychodzi badaczom oddzielenie problemów konstytucji i struktury osobistej tożsamości od problemów konstytucji i struktury osobistej indywidualności. Trudno przecież stwierdzić, w jakim stopniu poszczególne jednostki zaspokajają za sprawą konkretnych podstaw programowych, programów nauczania, podręczników - czy też rozmaitych działań dydaktyczno-wychowawczych - swoje podstawowe potrzeby, wynikające z biologicznej konstytucji ich organizmów lub czy potrafią dzięki nim nawiązywać prawidłowe relacje z otoczeniem społeczno-kulturowym. Można za to sprawdzić, w jaki sposób w tych dokumentach oraz praktyce edukacyjnej kształtowane są poszczególne typy tożsamości kolektywnych (grupowych, zbiorowych).

W tym celu odwołamy się do badania tekstów zamieszczanych $\mathrm{w}$ podręcznikach, będących podstawowym narzędziem zinstytucjonalizowanej socjalizacji całych pokoleń podlegających powszechnej edukacji ${ }^{1}$. Będą to książki przeznaczone do nauczania języka polskiego w szkole podstawowej, przede wszystkim ze względu na to, że korzystają z nich wszyscy młodzi Polacy obowiązkowo uczęszczający do masowej szkoły podstawowej, ale także z powodu bogactwa ich treści - przede wszystkim zróżnicowania publikowanych w nich tekstów kultury oraz zadań kształcących rozmaite sprawności językowe oraz literacko-kulturowe. Przegląd książek szkolnych publikowanych w różnych okresach historycznych pozwala zatem na próbę rekonstrukcji ustrukturyzowanego zespołu cech, w określonych kontekstach historyczno-politycznych uznanych za najistotniejsze i najbardziej pożądane w procesie socjalizacji i enkulturacji młodego pokolenia. Staną się one punktem odniesienia do współczesnego kontekstu edukacyjnego, w którym przebiega formowanie się kolektywnej tożsamości uczniów szkół podstawowych.

W szkolnej edukacji uwzględnia się jak największą liczbę czynników kształtujących osobowość, aby maksymalnie zwiększyć możliwość wpływania na jednostkę. Przyjmuję zatem, że kształtowanie tożsamości w sformalizowanym dyskursie edukacyjnym odbywa się na sześciu podstawowych płaszczyznach:

${ }^{1} \mathrm{~W}$ artykule wykorzystano materiał przykładowy i jego analizy zawarte w książce autorki. Zob. Rypel A. (2012). 
- psychologicznej, poprzez dążenie do indywidualnej identyfikacji z narodem, regionem, lokalną społecznością oraz ich ogólnie rozumianą kulturą, w tym także ukształtowane w jej ramach stereotypy ról płciowych;

- $\quad$ s o c j o l o g i c z n ej, poprzez uwzględnianie w świadomości zbiorowej podziału na „my” i „oni”. To antagonizowanie może przyczyniać się do utrzymywania lub przezwyciężania uprzedzeń i wynikającej z nich dyskryminacji społecznej, etnicznej lub narodowej;

- historycznej, poprzez jednostkowe i zbiorowe odwołania do dziejów narodu, regionu, miasta oraz bohaterów i instytucji historycznych;

- religijnej, poprzez odwołania do aksjologii i tradycji wybranej religii lub poprzez negowanie bądź przewartościowanie jej znaczenia dla danej zbiorowości;

- geograficznej, poprzez przypisanie jednostki i zbiorowości do określonej przestrzeni oraz poprzez sposoby kulturowego kształtowania tej przestrzeni, np. na poziomie urbanistyczno-architektonicznym;

- kulturowej, poprzez budowanie świadomości dziedzictwa kulturowego i kompetencji kulturowej, a w tym umiejętności: odczytywania symboli, trafnego lokalizowania i rozumienia dziejących się wydarzeń, ich interpretowania oraz przewidywania dalszego biegu. Szczególną rolę odgrywa tu także kształcenie (względnie zaniechanie kształcenia) umiejętności odczytywania symboli, kodów i skryptów kulturowych właściwych innym kulturom (Rypel 2012, 176-177).

Poszczególne płaszczyzny przenikają się nawzajem, współuczestnicząc w tworzeniu różnego typu tożsamości (narodowej, regionalnej, lokalnej, globalnej i międzykulturowej oraz płciowej) w efekcie składających się na całość tożsamości społeczno-kulturowej, której kształt przekazują poszczególne podręczniki (por. Rypel 2012, 177).

Tożsamość narodowa jest istotnym składnikiem tożsamości społeczno-kulturowej. Za Antoniną Kłoskowską rozumiem ją jako:

Zbieżność subiektywnych postaw wielu ludzi odnoszonych do własnej grupy kulturowej (...), świadomość pewnej odrębności od obcych i poczucie związku z grupą swoich oraz świadomość ciągłości, historycznego trwania tej grupy i jej zbiorowej filiacji - wywodzenia się od wspólnych przodków czy przodka (Kłoskowska 1992, 134)².

Jest to zatem rodzaj wzorca, który modeluje identyfikacje

2 Zbliżony sposób definiowania tożsamości narodowej przyjmuje również Zbigniew Bokszański, według którego jest to zbiór „przekonań, postaw i emocji, który zostaje ukształtowany w świadomościach członków zbiorowości narodowej w związku z poczuciem więzi z narodem i przeżywaniem przez nich uczestnictwa w grupie narodowej. Są to przekonania, postawy i emocje poddające się $\mathrm{w}$ istotnym zakresie procesom upodobnienia i uniformizacji (...). Podobieństwo treści poznawczych, postaw i emocji wielu jednostek zogniskowanych wokół więzi z macierzystą zbiorowością narodową pozwala na charakterystykę tożsamości tej zbiorowości (Bokszański 2005, 133). 
ze zbiorowością narodową w trakcie procesów socjalizacyjnych lub upowszechnione wzory reakcji na symbole narodowe, wzory określające pamięć przeszłości, wzory postaw wobec wybranych postaci i wydarzeń z przeszłości narodu (Wysocki 2017, 59).

Celem artykułu jest prześledzenie zasobu i trwałości symboli wzmacniających lojalność i poczucie zakorzenienia w danej zbiorowości, a także sposobu, w jaki te symbole, legitymizują aktualne instytucje, idee i systemy norm oraz kompensują niepowodzenia w życiu społecznym i gospodarczym. Szczególnie interesować mnie będę symbole odwołujące się do uniwersalnych archetypów (np. mowy ojczystej, ziemi ojczystej, bohatera) czy powszechnych mitów kulturowych (np. mitu początku). Odsyłając do odmiennych treści, służą one bądź do konstruowania tradycji narodowych z utrwalonych w świadomości zbiorowej elementów przeszłości, bądź do wynajdowania tradycji legitymizujących zmiany polityczne i gospodarcze.

Tożsamość narodowa krystalizuje się wprawdzie stopniowo na drodze rozmaitych procesów socjalizacyjnych, jednak w porównaniu do innych typów tożsamości społeczno-kulturowej, najsilniej ulega zinstytucjonalizowanym wpływom, przede wszystkim za pośrednictwem enkulturacyjnych zabiegów prowadzonych w szkole, zwłaszcza w ramach nauczania języka narodowego i kultury narodowej. W stuletnich dziejach szkolnictwa w odrodzonej Polsce zawsze istniały dokumenty programowe obowiązujące w każdym typie szkół; niezależnie od tego, czy nazywano je instrukcjami, programami nauczania, minimum programowym, czy (jak obecnie) podstawami programowymi, zawsze zawierały elementy eksplicytnie odnoszące się do budowania tożsamości narodowej. Nie inaczej jest w aktualnie obowiązującej podstawie programowej:

Ks ztałcenie ogólne w szkole podstawowej ma na celu:

- (1) wprowadzenie uczniów w świat wartości, w tym ofiarności, współpracy, solidarności, altruizmu, patriotyzmu i szacunku dla tradycji, wskazywanie wzorców postępowania i budowanie relacji społecznych, sprzyjających bezpiecznemu rozwojowi ucznia (rodzina, przyjaciele),

- (2) wzmacnianie poczucia tożsamości indywidualnej, kulturowej, narodowej, regionalnej i etnicznej

C e l e k s z t a ł c e n i a - wymagania ogólne

Kształcenie literackie i kulturowe

- (5) kształcenie postawy szacunku dla przeszłości i tradycji narodowej

Kształcenie językowe

- (1) rozwijanie rozumienia wartości języka ojczystego oraz jego funkcji w budowaniu tożsamości osobowej ucznia oraz wspólnot: rodzinnej, narodowej i kulturowej (Dz.U. 2017, poz. 356).

Te ogólne zapisy przywołują takie pojęcia, jak: patriotyzm, przeszłość, tradycja narodowa i tożsamość narodowa. Konkretyzacja tych pojęć niezależnie od okresu, w którym publikowane były podręczniki zgodne z danym dokumentem programowym, odnosiła się do następujących elementów: język, terytorium, symbole narodowe, wydarzenia historyczne, bohaterowie narodowi, religia i obcy (por. Rypel 2012, 177). 
W podręcznikach do języka polskiego niejednokrotnie wprost wskazuje się na wymienione składniki tożsamości narodowej, np.:

Uzupełnij podane zdania i przepisz je do zeszytu.

- Najważniejszą cechą naszej narodowości jest język polski.

- Polskim hymnem narodowym jest Mazurek Dąbrowskiego.

- Barwy Polski to kolory biały i czerwony.

- Godłem Polski jest biały orzeł.

- Stolicą Polski jest Warszawa (Nagajowa 1994, 283).

- Polskie symbole państwowe

- Opowiedz o kilku ważnych wydarzeniach z przeszłości naszej ojczyzny.

- Przedstaw sylwetkę sławnego rodaka, opowiedz o jego dokonaniach dla ojczyzny lub całego świata.

- Zastanów się nad tym, co to znaczy kochać swoją ojczyznę.

- Podaj te cechy, które twoim zdaniem:

- wyróżniają Polaków spośród Europejczyków,

- są wspólne dla Polaków i innych mieszkańców Europy.

- Opisz taki zwyczaj, który:

- kultywowany jest tylko przez Polaków,

- znany jest wszystkim Europejczykom.

- Dokładnie opisz polski sztandar i godło (Łuczak, Murdzek 2001, 202).

Poczucie tożsamości narodowej zależy jednak od wielu czynników, zwłaszcza od doraźnych okoliczności i wydarzeń oraz tła społecznego, na którym pojawia się refleksja odnosząca się do własnej wspólnoty (por. Łastawski 2014, 75-86). Aby je zrekonstruować, trzeba $\mathrm{z}$ jednej strony wydobyć składniki najbardziej trwałe, które tworzą jądro pojęcia, a z drugiej - wskazać elementy zależne od czynników subiektywnych i szerokiego kontekstu społeczno-kulturowego.

W centrum elementów tożsamości narodowej usytuować można język ojczysty - polską mowę, która w podręcznikach pełni szczególną funkcję - jest nośnikiem postaw patriotycznych, wiedzy historycznej, objaśnia symbole i stanowi tworzywo literatury, a jednocześnie, na mocy tych faktów, sama $\mathrm{w}$ sobie stanowi autonomiczny topos ${ }^{3}$ narodowy. Polacy należą do tych grup etnicznych, które od dawna kładą nacisk na język jako nośnik ich kultury oraz główne narzędzie obrony przed asymilacją. Z władania nim czynią warunek konieczny bycia „autentycznym” członkiem narodu. Warunku tego nie stawiają m.in. Irlandczycy i Żydzi - można być irlandzkim nacjonalistą, nie władając językiem celtyckim, można też identyfikować się z kulturą żydowską, nie znając jidysz lub hebrajskiego.

Taki stosunek Polaków do języka ojczystego ma swoje korzenie w oczywistym kontekście historycznym zaborów. W wyniku bezwzględnych zabiegów rusyfikacyjnych i germanizacyjnych język nabrał znaczenia wartości rdzennej (por. Smolicz 1990, 212-213) i stał się konstytutywnym składnikiem

\footnotetext{
3 Toposy traktuję jako wspólne zaplecze pojęciowe uczestników dyskursu i rezerwuar punktów odniesienia, koncentrujących uwagę i służących do eksponowania wybranych sądów. Tak rozumiane mają znaczenia typowe i powszechnie akceptowane w danej kulturze, ale ich interpretacja i nacechowanie aksjologiczne zmieniają się w zależności od tego, jaki jest cel argumentacji, dla której są punktem wyjścia. Toposy nie są więc polisemantyczne w tradycyjnym rozumieniu tego słowa, można raczej mówić o profilowaniu ich znaczeń zależnie od perspektywy przyjętej przez użytkowników języka (Rypel 2012, 25).
} 
polskości. Tak powstała nierozerwalna więź między językiem polskim a istnieniem narodu polskiego jako odrębnej grupy społecznej i kulturalnej.

Ten sposób myślenia przyczynił się do powstania narodowego toposu „mowy ojczystej”. W podręcznikach można znaleźć następujące modele jego odczytywania - mowa ojczysta to zatem: (1) język religii, współtworzący sferę sacrum; (2) język rodziny, wzmacniający więzi między ludźmi i przydający im głębszego, duchowego wymiaru; (3) nośnik tradycji, zapewniający międzygeneracyjną ciągłość kulturową; (4) wyznacznik polskości, niezależny od terytorialnego przypisania jednostki - jesteś Polakiem, ponieważ mówisz po polsku, a nie wyłącznie dlatego, że mieszkasz w Polsce. Odczytania te znajdują $\mathrm{w}$ podręcznikach liczne potwierdzenia $\mathrm{w}$ takich kanonicznych tekstach, jak przede wszystkim: Rota Marii Konopnickiej, Lekcja polskiego (fragment Syzyfowych prac) Stefana Żeromskiego, Latarnik i Wspomnienie z Maripozy Henryka Sienkiewicza. Częstotliwość występowania tego toposu zmienia się w zależności od kontekstu historycznego i nacechowania ideologicznego. W dwudziestoleciu międzywojennym nie był on szczególnie eksponowany, ponieważ ideą scalającą wieloetniczną i wielokulturową społeczność mieszkającą na obszarze Rzeczypospolitej była idea państwa, zaś między 1948 a 1956 dążono do tego, aby przywiązanie do polszczyzny zastąpić (zresztą nieskutecznie) internacjonalistycznym, ponadnarodowym i ponadpaństwowym pojęciem „mowy słowiańskiej”. Od połowy lat 60. minionego wieku nastąpił powrót do tradycyjnego rozumienia symbolu mowy ojczystej, o czym świadczą choćby tytuły podręczników do szkoły podstawowej: Mowa ojczysta (Sufin, Świerczyńska 1965), Ojczyste słowo (Sufin 1976), Polska mowa (Nagajowa 1981), Mowa rodzinna (Sufinowa 1984), W ojczyźnie-polszczyźnie (Dietrich 1994). Od połowy lat 90 . tytuły podręczników wskazują na nową tendencję - narodowy topos „mowy ojczystej” został wyparty przez bardziej uniwersalny topos „słowa”, przywołujący ogólne skojarzenia z ekspresywną, informacyjną i estetyczną funkcją języka, np.: Słowo za słowem (Nagajowa 1994), Słowa zwykłe i niezwykłe (Nagajowa 1995), Świat w słowach i obrazach (Nagajowa 1999), $W$ krainie słowa (Branicka, Chołuj, Czop i in. 2000), Słowa, litery, świat (Madejowa, Maj 2001), Słowa na start! (Derlukiewicz 2005), Daje słowo! (Klawe, Marszałek, Ciesielska i in. 2005), Bliżej słowa (Horwath, Kiełb 2009), Swoimi słowami (Brożek, Ciesielska, Pułka, Zych 2009), Słowa na czasie (Chmiel, Herman, Pomirska i in.), Jest tyle do powiedzenia (Marciszuk, Kosyra-Cieślak, Załazińska 2010), Czas na polski (Muszyńska, Grzymała 2009), Po polsku (Malczewska, Olech, Adrabińska-Pacuła 2009), Słowa z uśmiechem (Horwath, Żegleń 2017), Myśli i słowa (Nowak, Gaweł 2017).

Przytoczone tytuły na ogół dobrze oddają charakter treści podręczników, które przede wszystkim koncentrują się na kształceniu pragmatycznych umiejętności porozumiewania się i autoekspresji oraz ukazują związki języka z kulturą, a także etyczny wymiar komunikacji językowej. Świadczy

Polonistyka. Innowacje

Numer 11, 2020 
to o tym, że język ojczysty, postrzegany przede wszystkim jako narzędzie budowania szeroko rozumianej tożsamości społeczno-kulturowej, traci stopniowo swoje uprzywilejowane miejsce $\mathrm{w}$ zinstytucjonalizowanym kształtowaniu tożsamości narodowej. Jako przykład tej tendencji niech posłuży fragment noty biograficznej Josepha Conrada z gimnazjalnego podręcznika Świat w słowach i obrazach:

Możesz się czuć dumny z tego, że był z pochodzenia Polakiem. Urodził się bowiem w Polsce jako Józef Teodor Korzeniowski. Języka angielskiego nauczył się jako dorosły człowiek i w posługiwaniu się nim został mistrzem (powinno cię to zachęcić do nauki języka obcego) (Nagajowa 1999, 132).

Tę tendencję zdają się potwierdzać wyniki badań ankietowych. Z analiz ankiety przeprowadzonej w 1998 roku przez Kazimierza Przyszczypkowskiego wynikało, że

język polski sytuuje się bardzo wysoko na skali wyznaczników tożsamości (identyfikacji) narodowej. Na język polski jako ważny wyznacznik tożsamości narodowej wskazało w jego badaniach 89\% respondentów. Badania Przyszczypkowskiego pokazały, że język polski jest nie tylko najważniejszym kulturowym wyznacznikiem polskości, lecz w ogóle pierwszym i najpoważniejszym jej determinantem (cyt. za Walczak 2013, 121-122),

natomiast z badań przeprowadzonych w 2017 roku przez Emilię Bańczyk wynika, iż tylko dla nieco ponad połowy respondentów język polski jest czymś więcej niż przede wszystkim środkiem komunikacji. Co istotne, uczestnicy badań byli studentami filologii polskiej, „dla których język powinien być wartością autoteliczną. Można przypuszczać, że w innej grupie badawczej wynik ten byłby niższy" (Bańczyk 2019, 87). Konstatację o przewadze instrumentalnego traktowania języka ojczystego potwierdzają również badania przeprowadzone wśród studentów kierunków technicznych na Uniwersytecie Techniczno-Przyrodniczym w Bydgoszczy (Rypel 2017).

Kolejnym elementem konstytuującym tożsamość narodową jest uniwersalny topos „ziemi ojczystej”, porządkujący zbiorowe wyobrażenia o terytorialnym zasięgu każdej wspólnoty narodowej. Niekiedy trudno te wyobrażenia oddzielić od przekonań konstytuujących tożsamość lokalną, związaną z pojęciem „małej ojczyzny”. Należy zatem skupić się na wyszukaniu tych miejsc wspólnych, które zachowują swoje znaczenie niezależnie od kontekstu historycznego, a dzięki swej niezmienności i trwałości mają dla polskiej tożsamości narodowej charakter archetypiczny.

Takim narodowym toposem, przypisującym kategorię polskości do określonego terytorium, jest topos „Wisły - królowej (matki) rzek polskich". Wyznacza on obszar rdzennej, jednorodnej etnicznie Polski i ustala wertykalny sposób jego opisywania - od gór do morza. Siła tego symbolu zasadza się na tym, że bieg Wisły, od jej źródła na południu, do ujścia w Bałtyku na północy, wyznacza naturalne granice Polski, niezmienne, tak jak niezmienne jest położenie gór (Karpat, Tatr) i morza oraz bieg rzeki. 
Tym samym Polska, wpisana $\mathrm{w}$ odwieczny krajobraz, przejmuje cechę jego trwałości i dawności. Punktami stałymi w przestrzeni organizowanej przez Wisłę są wymieniane w podręcznikowych tekstach miasta: Kraków, Kazimierz, Warszawa, Włocławek, Toruń, Gdańsk. Ich nazwy współtworzą „jądro polskości”, trwające niezależnie od kształtu czy nawet istnienia państwa polskiego. Daty wydań podręczników, w których pojawił się symbol Wisły, wskazują, że z biegiem lat tendencja do jego przywoływania maleje ${ }^{4}$, a współcześnie niemal zanika. Na taki stan rzeczy wpływa zapewne stabilna sytuacja terytorialna państwa polskiego, ale przede wszystkim coraz wyraźniejsze wpływy kultury liberalnej, w której ojczyzna to miejsce, gdzie są moi przyjaciele i ludzie, których kocham. Zgodnie z tym założeniem, nie jesteśmy przypisani do konkretnego miejsca geograficznego i możemy swoją ojczyznę indywidualnie wybierać, zależnie od więzi z bliskimi ludźmi, niekoniecznie rodakami. Takie stanowisko wyraźnie koresponduje z nasilającą się mobilnością współczesnych Polaków, którzy swobodnie wybierają miejsce swojego osiedlenia i w warunkach różnie rozumianej emigracji redefiniują własną tożsamość narodową. Przed rokiem 1980 nie było w PRL problemu masowej emigracji czy to politycznej (poza $1968 \mathrm{r}$.), czy to zarobkowej, a kiedy po roku 1981 zaistniał - nie wolno było o nim pisać. Przemiany ustrojowe i gospodarcze zmieniły tę sytuację. Obecnie szacuje się, że około dwóch milionów Polaków okresowo lub na stałe podejmuje pracę za granicą. Wielu młodych ludzi już w trakcie nauki w szkole deklaruje chęć opuszczenia kraju. Tymczasem we współczesnych podręcznikach języka polskiego właściwie nie porusza się problemów związanych z osiedlaniem się naszych rodaków poza granicami kraju, a zwłaszcza konsekwencji tych wyjazdów.

W edukacji polonistycznej ciągle dominuje spetryfikowany obraz romantycznej Wielkiej Emigracji, a przecież jej przyczyny i charakter są tak odmienne od przyczyn i charakteru dzisiejszej ruchów migracyjnych, że trudno nawet porównywać rodzaj tęsknoty dziewiętnastowiecznego „żołnierza-tułacza" bez prawa powrotu do pozbawionej państwowości Polski, z tęsknotą emigranta z pierwszej połowy XXI, który najczęściej opuszcza kraj z przyczyn ekonomicznych lub osobistych. Topos „ziemi rodzinnej” wykorzystywany w poezji romantycznej odwoływał się do innych uniwersalnych toposów - „Arkadii” i „tęsknoty za rajem utraconym”. Sposób oddziaływania obu toposów opierał się na idealizowaniu kraju pochodzenia (najczęściej kraju sielskiego dzieciństwa), który ceni się tym bardziej, im bardziej jest

${ }^{4}$ Por. Jak szła Wisła do morza Marii Konopnickiej (Kubski, Dobraniecki 1936), Z biegiem Wisły. Kartki z notatnika Jana Michalskiego (Baculewski, Budzyk, Pietrusiewiczowa i in. 1948), Wiślane wianki Hanny Januszewskiej (Aleksandrzak, Koszutska 1951), Z biegiem Wisły Janiny Korczakowskiej (Aleksandrzak, Kwiecińska, Przyrowski, 1951), Do Gdańska Janiny Porazińskiej (Aleksandrzak, Przyrowski, 1957). W podręcznikach publikowanych już w XXI wieku podobnych tekstów praktycznie nie ma. Wyjątkiem jest wiersz Jerzego Ficowskiego Tutaj zamieszczony w podręczniku do IV kl. Między nami (Łuczak, Murdzek 2001), w którym symbol Wisły posłużył do uporządkowania opisów krajobrazu i przyrody. Jednocześnie symbol ten jest jedynym sygnałem polskości, pozwalającym nadać charakter narodowy opisywanym zjawiskom: (...) Tutaj pająk w swa siatkę kroplę rosy złowił,/ tu ważka jak kokarda na trzcinie zawisła,/sroczka skrzeczy na płocie: "Jada goście nowi!"/i od gór aż do Gdańska niebo spławia Wisła (podkreślenie - A.R.). 
niedostępny. We wszystkich analizowanych tu podręcznikach (za wyjątkiem podręczników wydawanych w latach 1949-1957) poza Inwokacja toposy „Arkadii” i „raju utraconego” pojawiają się również w takich kanonicznych tekstach, jak: W pamiętniku Zofii Bobrówny, hymn Tęskno mi, Boże Juliusza Słowackiego oraz Moja piosnka (II) Cypriana K. Norwida.

We współczesnych programach i podręcznikach języka polskiego trudno dopatrzeć się innej niż romantyczna, koncepcji budowania związków z ziemią rodzinną ${ }^{5}$, a przecież w dwudziestoleciu międzywojennym takie próby podejmowano. Mimo wielkiej żywotności mitów romantycznych, autorzy podręczników, oprócz tekstów przybliżających Wielką Emigrację, zamawiali także czytanki poruszające problem tożsamości narodowej Polaków, którzy opuścili Polskę za chlebem i w poszukiwaniu lepszych warunków życia osiedlili się w Brazylii, Stanach Zjednoczonych lub w Westfalii. Redefinicji związku Polaków z ojczyzną podjęła się wówczas między innymi Maria Dąbrowska w czytance Nasi ludzie $w$ Westfalii. Pisarka dobitnie uwypukla w niej różnice między dziewiętnastowieczną a dwudziestowieczną emigracją oraz wskazuje nowe źródła budowania tożsamości narodowej na obczyźnie. W aktualnych podręcznikach, choć problem czasowej lub stałej emigracji dotyka niemal każdą rodzinę, nie podejmuje się tej tematyki wcale, podczas gdy w programach z lat 70. jako lekturę obowiązkową zalecano opowiadanie Dąbrowskiej Marcin Kozera - opowieść o odkrywaniu polskiej tożsamości narodowej przez mieszkającego w Londynie i uczącego się w angielskiej szkole syna polskich emigrantów. Opowiadanie to zniknęło z programu zatwierdzonego w 1981 roku i w żadnym z kolejnych dokumentów programowym już się nie pojawiło. Współczesna polska szkoła konserwuje zatem tradycyjny model wiązania tożsamości narodowej wyłącznie z „ziemią ojczystą”, podczas gdy - jak zauważa Jerzy Bartmiński:

Koncepcje ojczyzny w środowiskach emigrantów i Polaków poza granicami kraju są zróżnicowane, od akceptacji nowego miejsca, po szukanie syntezy „zrastania się w jedno” przestrzeni nowej i starej i tworzenie rozróżnień typu: „Macierz” (Polska) - „Ojczyzna” (nowy kraj zamieszkania) (Bartmiński 1993, 43).

Do najbardziej eksponowanych w podręcznikach form symbolizacji należą flaga, godło i tekst hymnu, które w polskich warunkach stanowią zarówno materialny wyraz suwerenności państwa, jak i niezależny od jego istnienia znak wspólnoty narodowej. Andrzej Tarczyński, oprócz najbardziej oczywistej funkcji symbolu - spójności społecznej, przypisuje im również

\footnotetext{
${ }^{5}$ Podobnie, jak nie istnieje spójna koncepcja programów i podręczników nauczania języka i kultury polskiej dla dzieci polskich emigrantów w Niemczech, Irlandii, Wielkiej Brytanii czy Stanach Zjednoczonych, choć w krajach tych działają liczne szkoły niedzielne organizowane dla tych dzieci przez lokalne organizacje polonijne lub nawet przez specjalne agendy rządowe państw osiedlenia, które prowadzą $\mathrm{w}$ ten sposób swą politykę między- lub multikulturową. Próbę zmiany tej sytuacji podjęło Ministerstwo Edukacji Narodowej, zlecając przygotowanie podstawy programowej dla uczniów polskich uczących się za granicą oraz serii programów do nauczania języka polskiego: Rok polski (dla uczniów w wieku 5-9 lat), Własna droga do kraju przodków (dla uczniów w wieku 10-13 lat) i Moja polska kulturoteka (dla młodzieży powyżej 14. roku życia). Programy te są dostępne na stronie internetowej Ośrodka Rozwoju Polskiej Edukacji za Granicą http://www.orpeg.pl/index.php/ materialy/edukacja-wczesnoszkolna-i-jezyk-polski/programy-nauczania/862-moja-polska-kulturoteka-program-nauczania-jezyka-polskiego, [dostęp 12.09.2019].
} 
funkcję legitymizującą określone instytucje czy stosunki władzy oraz funkcję socjalizującą, którą pełnią jako narzędzia wpajania pewnego systemu wartości i określonego typu zachowań (Tarczyński 2008, 52). Z tego powodu, nie tylko w Polsce, stają się one ważnymi składnikami prowadzonej w szkołach edukacji narodowej i propaństwowej. Powszechne odwoływanie się do takich symboli narodowych, jak flaga, godło i hymn sprawia, że mimo lokalnych różnic mają one charakter uniwersalny. Oprócz nich można w podręcznikach wyodrębnić także symbole wyłącznie narodowe, ukształtowane pod wpływem specyfiki polskiego kontekstu historyczno-kulturowego.

$\mathrm{W}$ związku z tym, że na polskiej fladze (poza banderą) nie widnieją żadne dodatkowe atrybuty służące do kreowania narracji dziejów i cnót narodu, interpretacja jej symboliki ogranicza się do objaśniania znaczenia dwóch barw. Zgodnie z wykładnią heraldyczną kolor biały to reprezentacja srebra, oznacza także wodę, a w zakresie wartości duchowych czystość i niepokalanie, kolor czerwony symbolizuje zaś ogień oraz cnoty odwagi i waleczności (Russocki, Kuczyński, Willaume 1978). Analizując teksty zamieszczane w podręcznikach, zauważyć można dwojaką wykładnię semantyki tych barw, w zależności od tego, jakiej argumentacji służy symbol „biało-czerwonej”. Interpretacja kolorów zmienia się ze względu na to, czy cele perswazji dotyczą wojny czy pokoju. Podane w tabeli 1. zestawienie obrazuje wyekscerpowane z podręczników symbole kojarzone z barwami narodowymi wraz z uogólnionymi kontekstami ich użycia oraz konotowanymi przez nie wartościami.

\begin{tabular}{|l|l|l|l|}
\hline \multicolumn{2}{|l|}{$\begin{array}{l}\text { Kontekst interpretacji barw } \\
\text { flagi polskiej }\end{array}$} & Biel & Czerwień \\
\hline Wojna & Symbol & Woda & Krew \\
\cline { 2 - 4 } & $\begin{array}{l}\text { Kontekst użycia } \\
\text { symbolu }\end{array}$ & Woda obmywająca rany & Krew poległych \\
\cline { 2 - 4 } & $\begin{array}{l}\text { Konotowane war- } \\
\text { tości }\end{array}$ & $\begin{array}{l}\text { Czystość, szlachetne in- } \\
\text { tencje }\end{array}$ & Bohaterstwo, poświęcenie \\
\hline Pokój & Symbol & Serce & Róża \\
\cline { 2 - 4 } & $\begin{array}{l}\text { Kontekst użycia } \\
\text { symbolu }\end{array}$ & Czyste serce & Piękno ojczyzny \\
\cline { 2 - 4 } & $\begin{array}{l}\text { Konotowane war- } \\
\text { tości }\end{array}$ & Niewinność, dobra wola & Miłość \\
\hline
\end{tabular}

Tabela 1. Zależne od kontekstu różnice w interpretacji kolorów polskiej flagi państwowej (źródło: Rypel 2012, 192).

Należy podkreślić, że niezależnie od okresu, z którego pochodzi analizowany podręcznik, zdecydowanie przeważają konteksty związane z wojną, w których symbol „biało-czerwonej” ewokuje takie wartości, jak: męstwo, odwaga cywilna, bohaterstwo na polu chwały, poświęcenie. Sztandar to święty żołnierza znak (Aleksandrzak, Przyrowski 1963, 57), duma i godność żołnierza (Nagajowa 1994, 2018). Zdecydowanie mniejszą reprezentację 
mają natomiast konteksty, w których barwy narodowe przekonują do pracy dla dobra ojczyzny, rozwoju jej potencjału gospodarczego czy naukowego. Pojawiają się one głównie w podręcznikach wydawanych i wznawianych w latach 70. XX wieku, w okresie tzw. „propagandy sukcesu”.

Stosunkowo rzadkie odwołania do wymowy symbolicznej barw narodowych sprawiają, że flaga sprowadzona jest w podręcznikach do dwóch podstawowych wymiarów: reprezentacyjnego i rytualnego. Zastosowanie toposu „biało-czerwonej” w wymiarze reprezentacyjnym ukazuje flagę jako znak:

- identyfikujący Polaków na obczyźnie, por. teksty: Biało-czerwona chorągiew (Tync, Gołąbek 1936, 136-139), Mazurek Dąbrowskiego (Aleksandrzak, Przyrowski 1963, 119-200);

- $\quad$ potwierdzający polskie osiągnięcia, por. tekst Na północnym wierzchołku Ziemi (Łuczak, Murdzek 2001, 272-274), a w warstwie ikonicznej rysunek Wielka przygoda (Kowalczykowa, Mrowcewicz 1999, 40);

- $\quad$ świadczący o przynależności państwowej, por. teksty Zamek (Kubski, Dobraniecki 1936, 76), Westerplatte (Aleksandrzak, Przyrowski 1963, 302-304), zadania do tekstu Cześć banderze (Nagajowa 1994, 282), tytuł działu Polskie symbole państwowe (Derlukiewicz 2005, 18).

Jednak częściej flaga przedstawiana jest w wymiarze rytualnym, to znaczy jako nieodzowny element obchodów rocznic, jubileuszy, świąt oraz uroczystości państwowych i szkolnych, podczas których traktowana jest jako element obowiązkowego patriotycznego rytuału, w którym barwy narodowe stanowią części często bezrefleksyjnie traktowanego sztafażu. W warstwie ikonograficznej dokumentują to zjawisko między innymi fotografie z uroczystości szkolnych, podczas których dzieci przyklękając, ślubują na sztandar lub przepasane biało-czerwonymi szarfami tworzą poczet sztandarowy. Trudno potępić takie treści, warto jednak zwrócić uwagę, że powinny być one stosownie zrównoważone innymi kontekstami, w których topos „biało-czerwonej” będzie używany na rzecz pogłębionego rozumienia patriotyzmu. Ten ton namysłu nad obrzędowym charakterem wielu przejawów polskiego patriotyzmu ma wiersz Jana Kasprowicza Rzadko na moich wargach. Zamieszczano go w podręcznikach z lat 30., 70., 80. i 90., znalazł się nawet w książkach wydanych w 1946 roku, natomiast w podręcznikach wydanych po roku 2000 już go nie znajdziemy.

Tymczasem młodzi ludzie sami dokonują przewartościowania polskich symboli narodowych. Polem dla tych działań jest Internet. W jego przestrzeni łatwo jest manifestować brak poczucia jakichkolwiek ograniczeń moralno-obyczajowych i bezkarnie atakować również symbole narodowe. Zjawisko to zaobserwować można między innymi w memach, które przedstawiają godło Polski, biało-czerwoną flagę, bohaterów narodowych lub ważne dla historii Polski wydarzenia (por. il. 1, 2). 


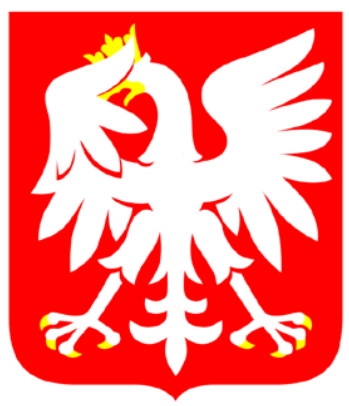

Ilustracja 1. Orzeł wstydu - godło Polski XXI wieku (Źródło: https://paczaizm.pl/orzelek-godlo-polski-zamyka-oczy-ze-wstydu-zakrywa-twarz-skrzydlem/) [dostęp: 18.09.2019].

\section{Co symbolizuje flaga Polski?}

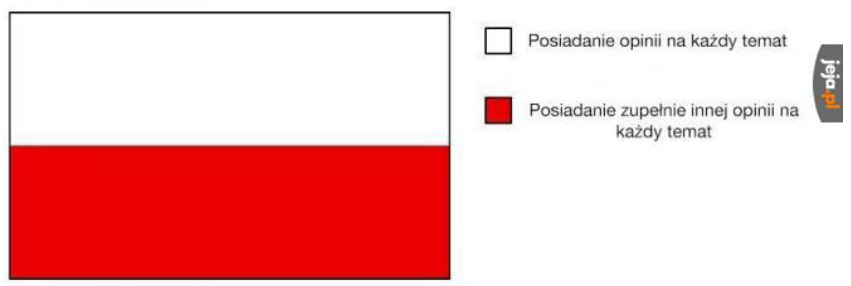

Ilustracja 2. Odwieczny konflikt (Źródło: https://memy.jeja.pl/szukaj.html?q=flaga\%20 Polski\&sw $=g \& s t r=3$ )

Liczne przykłady rekontekstualizacji tych symboli świadczą o zaangażowaniu ich twórców w sprawy publiczne, a deprecjacja narodowych symboli służy nie tylko temu, aby wyróżnić się spośród tysięcy innych memów, lecz także temu, by obnażyć bolesne dla Polski problemy lub zdemaskować przedmiotowe traktowanie symboli przez uczestników współczesnego dyskursu publicznego, np. podczas manifestacji organizowanych przez silnie zantagonizowane obozy polityczne czy grupy reprezentujące odmienne światopoglądy. W przestrzeni publicznej polska flaga kontrastowana jest lub zestawiana z flagą Unii Europejskiej lub z tęczową flagą reprezentującą środowiska LGBT - dla jednych symbolizuje silną więź z tradycję, dla drugich dumę narodową, dla jeszcze innych konserwatyzm, zawsze jednak w tych przypadkach używana jest instrumentalnie.

Nawiązywanie do powszechnie kojarzonej przez wielu Polaków ikonografii przedstawiającej wielkich Polaków wykorzystywane jest również do prowadzenia przez młodych, zaangażowanych ludzi różnego rodzaju akcji o odmiennym niż narodowy charakterze.

Przykładem zastosowania memów umieszczających postać polskiego bohatera narodowego Tadeusza Rejtana w nowym kontekście dla osiągnięcia jednoznacznego celu jest internetowa kampania nawołująca do bojkotu wyrobów firmy LPP. Protest społeczny został wywołany decyzją przedsiębiorstwa o przeniesieniu marek towarowych do zależnych spółek na Cyprze i w Zjednoczonych Emiratach Arabskich po to, by zmniejszyć podatki płacone w Polsce (Niekrewicz 2015, 119). 
Aktualna sytuacja polityczna w Polsce sprawia, że coraz bardziej różnicuje się społeczny odbiór symboli, które do tej pory powszechnie traktowano jako przedmiot dumy narodowej. Doskonałym tego przykładem jest Nagroda Nobla, która choć ma charakter uniwersalny, stanowi szczególny polski symbol narodowy. Odwołuje się do poczucia solidarności grupowej i dumy narodowej Polaków (Górą nasi!). Nie trzeba ani czytać, ani rozumieć twórczości Henryka Sienkiewicza czy Wisławy Szymborskiej, aby czuć się osobiście dowartościowanym ich sukcesem, podobnie, jak nie trzeba być katolikiem, aby cieszyć się z wyboru Karola Wojtyły na papieża lub być kibicem, by odczuwać dumę ze spektakularnych zwycięstw polskich sportowców. Nagroda Nobla zajmuje jednak szczególne miejsce i najlepiej obrazuje, w jaki sposób (w dużej mierze za pośrednictwem szkoły) budowane jest poczucie wspólnoty i wysokiej samooceny Polaków.

W zestawieniach zdobywców Nagrody Nobla Polacy sytuują się na dalekich pozycjach ${ }^{6}$. W tym wypadku siła symbolu nie polega jednak na liczbie nagród, która wyróżniałaby naszych rodaków spośród innych nacji, ale na powiązaniu tego międzynarodowego wyróżnienia z ideą narodową. Nastąpiło ono bardzo szybko, bo już w 1905 roku, po zdobyciu nagrody literackiej przez Henryka Sienkiewicza7. Czytanka Nagroda Nobla dokumentuje źródła związku między patriotyzmem a wyrażanym przez cudzoziemców uznaniem dla polskich osiągnięć:

Chwała spada na cały kraj. Sienkiewicz jest Polakiem, a w nim uczczono Polskę. Oznajmiono całemu światu, że książka polska jest wspaniała i godna tego, aby ją cały świat wielbił. W tej chwili na całej kuli ziemskiej powtarzają jego nazwisko. W najdalszych krańcach ziemi mówią o Polsce. Dowiadują się z podziwem, że ten naród, choć w niewoli, nie przestał ani na jedną chwilę żyć i tworzyć. Teraz widzą, że duch polski wiecznie żyje i płonie, jak niezmierne ognisko.

Książki Sienkiewicza wędrują po całej ziemi. A są one tak śliczne, że każdy je czyta. Obcych ludzi uczą one o Polsce, o jej przeszłości, o jej potędze i o jej nieśmiertelności. Dzięki Ci Boże! (Tync, Gołąbek 1936, 55).

Podręczniki języka polskiego w niepodległej Polsce utrwalały przekonanie o istnieniu ścisłego związku między miłością do ojczyzny a międzynarodowymi sukcesami Polaków ${ }^{8}$ i w efekcie, dla kolejnych pokoleń uczniów, Nagroda Nobla stała się swoistym toposem narodowym, dostarczającym przesłanki do wysokiej samooceny, niezależnej od osobistych zasług i możliwości oraz niepowodzeń odnoszonych przez naród lub państwo. Obecnie jednak sposób traktowania Nagrody Nobla zmienia się radykalnie. Zmianę tę można było zauważyć już wtedy, kiedy wyróżnienie to przyznano Wisławie

\footnotetext{
${ }^{6}$ Dla porównania: USA - 320 laureatów, Wielka Brytania - 116, Niemcy - 103, Francja - 54, Szwecja - 28, Polska - 7.

7 Przypomnijmy, że Nagroda Nobla przyznawana jest od 1901 roku.

${ }^{8}$ Por. fragment czytanki Alfred Nobel z podręcznika Droga do jutra, w którym mowa jest o reakcjach szwedzkiej prasy na przyznanie Władysławowi S. Reymontowi Nagrody Nobla: Pisano w „Svenska Dagbladet” (...) „Nagrodzenie zaś Polaka było także dowodem sympatii Szwedów dla duchowej kultury wysoce uzdolnionego polskiego narodu w chwili triumfu wskrzeszonej Polski” (Lausz, Zwierzchowska-Ferencowa 1947, 377).
} 
Szymborskiej, jednak skutki tej przemiany najlepiej zobrazowały silnie spolaryzowane komentarze po przyznaniu Nagrody Nobla Oldze Tokarczuk.

W artykule przedstawiono zaledwie kilka wybranych przykładów wykorzystywania i redefiniowania toposów narodowych. Wypada jednak wspomnieć, że te odwołujące się do poszczególnych symboli narodowych, państwowych oraz wydarzeń i bohaterów historycznych toposy organizowane są w pewien kompleks (czyli w pewną całość pojęciową) przez określony mit historyczno-polityczny (zob. tab.2.).

\begin{tabular}{|l|c|c|c|}
\hline \multirow{2}{*}{ Rodzaje toposów } & \multicolumn{3}{|c|}{ Kompleksy toposów organizowane przez mity historyczno-polityczne } \\
\cline { 2 - 4 } & $\begin{array}{c}\text { Mit zalożycielski (mit } \\
\text { genezy) }\end{array}$ & $\begin{array}{c}\text { Mit niemieckiego } \\
\text { zagrożenia } \\
\text { Mit powstrzymania } \\
\text { niemieckiej ekspansji }\end{array}$ & $\begin{array}{c}\text { Romantyczny mit walki } \\
\text { o niepodleglość }\end{array}$ \\
\hline Symbol narodowy & Orzeł Biały & Bogurodzica & Mazurek Dąbrowskiego \\
\hline Symbol państwowy & Godło & Pierwszy polski hymn & Hymn \\
\hline Bohater narodowy & Lech & Władysław Jagiełło & Henryk Dąbrowski \\
\hline Miejsce & Gniezno & Grunwald & Reggio \\
\hline Wydarzenie historyczne & Początki państwa & Bitwa wojsk polsko- & Powstanie Legionów \\
& polskiego & -litewskich z Krzyżakami & Polskich we Włoszech \\
& & 15.07 .1410 r. & w 1797 r. \\
\hline
\end{tabular}

Tabela 2. Kompleksy toposów organizowane przez mity historyczno-polityczne (Źródło: Rypel, 2012, 221).

Pojawianie się danego mitu zależy od warunków i potrzeb społeczeństwa. Mityczne opisywanie rzeczywistości odpowiada konkretnym warunkom materialnym, aktualnym urazom, obawom, kompleksom i dążeniom. Jeśli znika ich źródło, wygasa także popularność mitu. Tak stało się na przykład z mitem Polski - przedmurza chrześcijaństwa. Współcześnie mity rodzą się i obumierają jeszcze szybciej, dlatego szczególnie interesujący wydaje się fakt, że wyróżnione tu trzy kompleksy toposów narodowych nie tylko przetrwały kilkanaście pokoleń, ale nadal przez autorów wielu podręczników uznawane są za istotne dla budowania tożsamości grupowej.

Na uwagę zasługuje fakt, że nie wszystkie $\mathrm{z}$ analizowanych podręczników współczesnych przywołują wymienione kompleksy toposów, w wielu z nich (np. To lubię!) pojawiają się tylko niektóre z ich komponentów. Istotny jest również fakt, że w miejsce dawnych „kanonicznych” kompleksów toposów narodowych nie powstają nowe, porządkowane przez mity zaspokajające potrzeby współczesnego społeczeństwa. Być może pokolenie „festiwalu Solidarności" nie ma potrzeby mitologizowania wydarzeń, które zmieniły społeczny, polityczny i kulturowy kształt Polski, a nowe kompleksy toposów narodowych będą kształtowane przez mit Jana Pawła II? Możliwe też, że w ciągle zmieniających się warunkach kulturowych autorom niektórych 
podręczników trudno jest ustalić właściwe proporcje między tym, co narodowe, a tym, co etniczne, regionalne i globalne. Dzieje się tak dlatego, że:

Współczesny świat dzieli się nadal na terytoria narodowe, ale procesy społeczne, ekonomiczne, kulturowe i demograficzne, z którymi mamy do czynienia w obrębie narodów, w coraz większym stopniu przekraczają tradycyjnie rozumiane granice narodowe i państwowe, identyfikowane dodatkowo z granicami odrębnych kultur (Burszta 1998, 158).

Dostępność i niska cena komunikacji powodują, że wszelkie idee, utwory, style, dobra materialne i niematerialne rozprzestrzeniają się dziś o wiele szybciej niż kiedykolwiek przedtem, prowadząc jednocześnie do powstania nowej jakości kultury, którą Anthony Giddens nazywa homogeniczną kulturą globalną ${ }^{9}$. W tej sytuacji najpoważniejszym wyzwaniem edukacji (także polonistycznej) staje się określenie właściwych proporcji między kulturą etniczną (a w jej obrębie także kulturą regionu), a kulturą kształtowaną na poziomie globalnym. Nie znaczy to, że mamy bezrefleksyjnie akceptować zjawiska takie, jak akulturacja ${ }^{10}$, dyfuzja kulturowa ${ }^{11}$ czy asymilacja ${ }^{12}$ i godzić się na erozję kultury narodowej, uznając ogólnoświatowe procesy za naturalne, a nawet do pewnego stopnia nieuniknione. Szkoła jest instytucją chroniącą, przekazującą i współtworzącą wartości kultury narodowej. Żywotność tej kultury, manifestująca się w realnym, a nie wyłącznie deklaratywnym, przywiązaniu do niej młodego pokolenia, zależy jednak od tego, w jaki sposób edukacja uwzględni wpływ przemian społecznych na związki z własną grupą etniczną i narodową.

Mobilność, będąca cechą charakterystyczną ponowoczesnych społeczeństw, sprawia, że coraz bardziej skomplikowany staje się proces budowania własnej tożsamości narodowej i kulturowej. David Hallinger zauważył, że kategoria tożsamości jest niejednorodna i zaproponował rozróżnienie na tożsamość i afiliację. Jego zdaniem „tożsamość ma charakter psychologiczny, jest nadana lub przypisana jednostce bez jej udziału i woli, cechuje się stałością, co oznacza, że posiadanie danej tożsamości wyklucza równoczesne przyjęcie innej. Afiliacja natomiast ma charakter zmienny, wymaga zgody jednostki, zakłada pewną swobodę wyboru i ma charakter

\footnotetext{
9 „Homogenizacja kultury”, czyli jej ujednolicenie, polega na zabiegu gruntownego pomieszania elementów różnego poziomu i przekazania ich w postaci jednolitej masy, w której na tym samym poziomie stawiane są elementy o bardzo zróżnicowanej wartości formalnej i artystycznej (por. Kłoskowska, 2005).

10 „Akulturacja” to ogół zjawisk, które powstały w wyniku bezpośredniego lub pośredniego kontaktu dwóch grup kulturowych. Efektem zderzenia kultur są zmiany wzorów kulturowych następujące w jednej lub obydwu kulturach. Mogą one prowadzić do unifikacji wzorów kulturowych lub przyjęcia wzorów dominujących przez jedną z grup. Reakcja na akulturację może mieć charakter asymilacji, integracji, separacji lub marginalizacji (por. Staszczak 1987, 17-19).

${ }_{11}$ „Dyfuzja kulturowa” polega na przenikaniu elementów stanowiących część jednej kultury do kultury odmiennej. Mogą to być np. zapożyczenia językowe, zwyczaje, które w rezultacie wpływają na zmianę postaw, a nawet systemu wartości. Dyfuzja zachodzi najczęściej między kulturami społeczeństw mających ze sobą bezpośrednią styczność (na drodze migracji, kontaktów handlowych). Dzięki mediom, kultury uważane za bardziej prestiżowe, mogą wpływać na zachowania znacznie bardziej zróżnicowanych społeczeństw. Nadmierna dyfuzja w wielu wypadkach prowadzi do akulturacji (Staszczak 1987, 63-65).

12 „Asymilacja” stanowi proces określający całokształt zmian społecznych i psychicznych, jakim ulegają jednostki, odłączając się od swojej grupy i przystosowując do życia w odmiennej kulturze (Staszczak 1987, 45-47).
} 
inkluzyjny. Zdaniem Hollingera, to właśnie pojęcie afiliacji, a nie tożsamości poprawnie charakteryzuje stosunek współczesnego człowieka do grup społecznych" (cyt. za Rokicki 2004, 267).

Warto także zaznaczyć, że wraz z postępującą płynnością materii społecznej, z góry zakładającą nietrwałość i doraźność, coraz trudniejsze staje się arbitralne ustalanie przekazywanych przez dyskurs edukacyjny wzorów kulturowych, ponowoczesny paradygmat kultury charakteryzuje się bowiem nietrwałością wszelkich podziałów i klasyfikacji, brakiem ciągłości, ahistorycznością oraz antykanonicznością jako konsekwencją tymczasowości. Dyskurs edukacyjny należy zatem postrzegać raczej jako pole afiliacji, w którym uczniów można przekonywać do wyboru określonego kształtu kultury (w tym także narodowej), a nie arbitralnie przymuszać do jej akceptowania. Afiliacja jako proces zakłada swobodę wyborów, dzięki którym jednostka weryfikuje, kim jest, kim się staje i kim chce być, a z czasem osiąga poczucie związku z kulturą narodową (lub etniczną), uznawaną za własną (por. Kłoskowska 2005, 161-162).

\section{Bibliografia}

Bańczyk Emilia, 2019, O roli języka w kształtowaniu tożsamości młodego pokolenia, „Postscriptum Polonistyczne” 1 (23), s. 239-259.

Bartmiński Jerzy, 1993, Polskie rozumienie ojczyzny i jego warianty, w: Pojęcie ojczyzny we współczesnych językach europejskich, Bartmiński J. (red.), Lublin, s. 23-48.

Bokszański Zbigniew, 2005, Tożsamości zbiorowe, Warszawa.

Budyta-Budzyńska Małgorzata, 2010, Socjologia narodu i konfliktów etnicznych, Warszawa.

Burszta Wojciech Józef, 1998, Antropologia kultury, Poznań.

Kłoskowska Antonina, 2005, Kultura masowa. Krytyka i obrona, Warszawa.

Kłoskowska Antonina, 2005, Kultury narodowe u korzeni, Warszawa.

Kłoskowska Antonina, 1992, Tożsamość i identyfikacja narodowa w perspektywie historycznej i psychologicznej, „Kultura i Społeczeństwo” 1 (36), s. 131-141.

Łastawski Kazimierz, 2014, Postrzeganie sąsiadów przez Polaków po 1989, „Stosunki Międzynarodowe - International Relations” 2, s. 75-86.

Niekrewicz Agnieszka, 2015, Językowe i wizualne sposoby deprecjonowania polskich symboli narodowych, kulturowych i religijnych $w$ memach internetowych, w: Język. Religia. Tożsamość XI. Język tożsamości, Cyral G., Skorupska-Raczyńska E. (red.), Gorzów Wielkopolski, s. 109-121.

Rokicki Jarosław, 2004, Zakorzenienie kosmopolity: czy jednostka może być wielokulturowa?, w: Naród, kultura, państwo w procesie globalizacji, Rokicki J., Banaś M. (red.), Kraków, s. 261-270.

Russocki Stanisław, Kuczyński Stefan K., Willaume Juliusz, 1978, Godło, barwy i hymn Rzeczypospolitej. Zarys dziejów, Warszawa. 
Rypel Agnieszka, 2017, Posłannictwo czy pragmatyzm - o zadaniach nauczyciela języka polskiego w czasach ponowoczesnych, w: Uczenie języka ojczystego w czasach ponowoczesnych, Tabisz A. (red.), Opole, s. 39-52.

Rypel Agnieszka, 2012, Edukacyjny wymiar dyskursu edukacyjnego. Na przykładzie podręczników języka polskiego z lat 1918-2010, Bydgoszcz.

Smolicz Jerzy, 1990, Język jako wartość rdzenna, w: Oblicza polskości, Kłoskowska A. (red.), Warszawa, s. 208-238.

Staszczak Zofia, 1987, (red.), Słownik etnologiczny. Terminy ogólne, Warszawa-Poznań, 17-19.

Straub Jurgen, 2006, Tożsamość osobista i zbiorowa. Analiza pojęciowa, w: Współczesne teorie socjologiczne, t. 2, Jasińska-Kania A., Nijakowski L.M, Szacki J., Ziółkowski M. (red.), Marody M. (przeł.), Warszawa, s. 1119-1134.

Tarczyński Andrzej, 2008, Tradycja, społeczne doświadczenie przeszłości, Toruń.

Walczak Bogdan, 2013, Język i wyznanie a tożsamość etniczna i narodowa dawniej i dziś, w: Językowa kreacja tożsamości, Cyran G., Skorupska-Raczyńska E. (red.), Gorzów Wielkopolski, s. 114-125.

Wysocki Artur, 2017, Poczucie tożsamości narodowej Polaków w kontekście zachodnioeuropejskim, „Opuscula Sociologica”, nr 3, s. 57-76.

\section{Źródła internetowe}

Rozporządzenie Ministra Edukacji Narodowej z dnia 14 lutego 2017 r. w sprawie podstawy programowej wychowania przedszkolnego oraz podstawy programowej kształcenia ogólnego dla szkoły podstawowej (...) Dz.U. 2017, poz. 356, https://www.google.com/search?client=firefox-b-d\& $q=$ Rozporzadzenie + Ministra + Edukacji + Narodowej+z+dnia $+14+$ lutego $+2017+r .+w+$ sprawie + podstawy+programowej (...) [dostęp: 12.10.2019]

Programy nauczania dzieci polskich za granicą: Rok polski (dla uczniów w wieku 5-9 lat), Własna droga do kraju przodków (dla uczniów w wieku 10-13 lat) i Moja polska kulturoteka (dla młodzieży powyżej 14. roku życia). http://www.orpeg.pl/index.php/materialy/edukacja-wczesnoszkolna-i-jezykpolski/programy-nauczania/862-moja-polska-kulturoteka-program-nauczaniajezyka-polskiego (...) [dostęp: 12.09.2019]

Orzeł wstydu - godło Polski XXI wieku, https://paczaizm.pl/orzelek-godlo-polskizamyka-oczy-ze-wstydu-zakrywa-twarz-skrzydlem/[dostęp: 18.09.2019]

Odwieczny konflikt,https://memy.jeja.pl/szukaj.html?q=flaga\%20 $\underline{\text { Polski\&sw }=g \& s t r=3}$ [dostęp: 18.09.2019]

\section{Wykaz cytowanych podręczników}

Aleksandrzak Stanisław, Koszutska Halina, 1951, Czytanki dla klasy III, Warszawa.

Aleksandrzak Stanisław, Kwiecińska Zofia, Przyrowski Zbigniew, 1951, „Na szerokiej drodze". Czytanki dla klasy IV, Warszawa.

Aleksandrzak Stanisław, Przyrowski Zbigniew, 1963, „A czy znasz ty, bracie młody...”. Czytanki dla klasy IV, Warszawa. 
Aleksandrzak Stanisław, Przyrowski Zbigniew, 1957, Czytanki dla klasy IV, Warszawa.

Baculewski Jan, Budzyk Kazimierz, Pietrusiewiczowa Jadwiga, Piorunowa Aniela, 1948, „Wczoraj i dziś”. Czytanki polskie dla gimnazjów zawodowych o ogólnokształcacych dla klasy I, Warszawa.

Branicka Joanna, Chołuj Halina, Czop Mirosław, Szczukowska Lucyna, Żurek Sabina, 2000, „W krainie słowa”. Podręcznik do języka polskiego klasa IV, Gdańsk.

Brożek Adam, Ciesielska Agnieszka, Pułka Małgorzata, Zych Daniel, 2009, „Swoimi słowami”. Podręcznik do kształcenia literackiego i kulturowego wraz ze szkoła pisania. Język polski dla gimnazjum, kl. 1, Warszawa.

Chmiel Małgorzata, Herman Wilga, Pomirska Zofia, Doroszewski Piotr, 2009, „Słowa na czasie”. Podręcznik do kształcenia literackiego i kulturowego dla klasy I gimnazjum, Warszawa.

Derlukiewicz Marlena, 2005, „Słowa na start!”. Podręcznik języka polskiego do kształcenia literackiego i kulturowego dla klasy IV szkoły podstawowej, Gdańsk.

Dietrich Joanna, 1991, „W ojczyźnie - polszczyźnie”. Język polski. Podręcznik do kształcenia literackiego i kulturalnego dla klasy VII szkoły podstawowej, Warszawa.

Horwath Ewa, Kiełb Grażyna, 2009, „Bliżej słowa”. Język polski. Podręcznik do kształcenia literacko-językowo-kulturowego. Klasa I gimnazjum, Warszawa.

Horwath Ewa, Żegleń Anita, 2017, „Słowa z uśmiechem”. Język polski dla klasy 4, Warszawa.

Klawe Elżbieta, Marszałek Hanna, Ciesielska Agnieszka, 2005, „Daję słowo!”. Język polski, klasa IV, Część 1 i 2, Warszawa.

Kowalczykowa Alina, Mrowcewicz Krzysztof, 1999, „Kto czyta, nie błązi”. Literatura i kultura. Język polski dla I klasy gimnazjum, Warszawa.

Kubski Benedykt, Dobraniecki Stanisław, 1936, „Na zagonie”. Czytanki polskie dla klasy II szkół powszechnych I stopnia, kurs A, Lwów.

Lausz Karol, Zwierzchowska-Ferencowa Zofia, 1947, „Droga do jutra”. Wypisy dla klasy VIII szkoły podstawowej, Warszawa.

Łuczak Agnieszka, Murdzek Anna, 2001, „Między nami”. Język polski. Podręcznik dla klasy IV szkoły podstawowej, Gdańsk.

Madejowa Maria, Maj Bronisław, 2001, „Słowa, litery, świat”. Podręcznik do języka polskiego, klasa IV, Warszawa.

Malczewska Jolanta, Olech Joanna, Adrabińska-Pacuła Lucyna, 2009, „Po polsku”. Literatura. Język. Komunikacja. Podręcznik do języka polskiego dla gimnazjum. Klasa I, Warszawa.

Marciszuk Teresa, Kosyra-Cieślak Teresa, Załazińska Aneta, 2010, „Jest tyle do powiedzenia". Język polski gimnazjum klasa I, Warszawa.

Muszyńska Izabela, Grzymała Joanna, 2009, „Czas na polski”. Podręcznik dla gimnazjalistów. Klasa I. Część 1 i 2, Warszawa. 
Nagajowa Maria, 1981, „Polska mowa”. Język polski. Podręcznik do kształcenia literackiego i kulturalnego oraz ćwiczeń w mówieniu i pisaniu dla klasy czwartej szkoły podstawowej, Warszawa.

Nagajowa Maria, 1994, „Słowo za słowem”. Podręcznik do kształcenia literackiego i językowego dla klasy IV szkoły podstawowej, Warszawa.

Nagajowa Maria, 1999, „Świat w słowach i obrazach”. Podręcznik do kształcenia literackiego i kulturalnego dla klasy pierwszej gimnazjum, Warszawa.

Nowak Ewa, Gaweł Joanna, 2017, „Myśli i słowa”. Podręcznik do języka polskiego, klasa VII, Warszawa.

Sufin Stanisława, 1976, „Ojczyste słowo”. Podręcznik dla klasy VII. Wypisy oraz ćwiczenia $w$ mówieniu i pisaniu, Warszawa.

Sufin Stanisława, Świerczyńska Aniela, 1965, „Mowa ojczysta”. Wypisy ćwiczeniami dla klasy VII, Warszawa.

Sufinowa Stanisława, 1984, „Mowa rodzinna”. Język polski. Podręcznik do kształcenia literackiego i kulturalnego dla klasy siódmej szkoły podstawowej, Warszawa.

Tync Stanisław, Gołąbek Józef, 1936, Czytanki polskie dla IV klasy szkół powszechnych I stopnia, kurs $C$, Lwów-Warszawa.

\section{O Autorce}

Agnieszka Rypel - dr hab., profesor uczelni, pracuje na Wydziale Językoznawstwa Uniwersytetu Kazimierza Wielkiego w Bydgoszczy. Jest autorką dwóch monografii oraz kilkudziesięciu artykułów, których tematyka dotyczy przede wszystkim: nowych koncepcji kształcenia językowego, a zwłaszcza tworzenia wypowiedzi pisemnych, ustaleń metodologicznych dotyczących dyskursu edukacyjnego oraz stosowanych w nim mechanizmów perswazyjnych, wychowania językowego, a także glottodydaktyki. 
